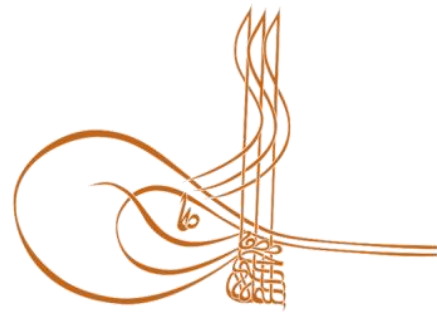

www.turkishstudies.net/religion
Turkish Studies - Comparative Religious Studies

eISSN: $2667-5544$

Research Article / Araștırma Makalesi

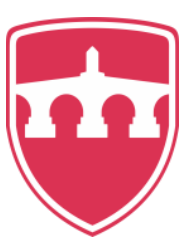

INTERNATIONAL BALKAN

UNIVERSITY

Sponsored by IBU

\title{
Kur’an Kırâatı ile Arap Dilbilimi Münasebeti Üzerine
}

The Approach of Linguists to Qirä 'àt and the Position of Sïbawayh

\author{
Aydın Kudat
}

\begin{abstract}
Arabic linguistics and quraa are twins on the basis of the basic aim that they are serving. There is an intense relationship between them in the context of source and hujjat. They refer to each other when basing the general application rules. Within the process, these two disciplines discussed among themselves, sometimes it was possible for mutual criticism. The two main issues on which the discussions are focusing is the issue of resource dimension and practicality reference. In this context, naqil, semā ${ }^{\prime}$, q1yas, illat ve istishhad are the most commonly used arguments. What could be the reason for the linguists to criticize various aspects of Qirāa $\bar{a}$ t for further arguments to justify the Arabic language grammars? What does Sībawayh's position in this regard and the attitude between these two disciplines mean for subsequent linguists? The grammar and the prioritising approach of qiyās have become widespread since the hegira of the third century. As a result of the activities that justify the quraat with multiple arguments, especially linguistics, there has been a tendency to choose among the aspects and some aspects have even been criticized. Those who see the grammatical and formalmushaf dimension of the issue as anterior could tend to highlight the qiyās, while choosing among different aspects. Those who see the sanad, mushâfaha telakki und tahammul dimensions of qiraa as anterior, showed a more cautious attitude about preference. In the context of the naql dimension of Qirā'āt, Arabic linguists are not as moderate as philologists. In this article, the attitude of Sibeveyhi will be discussed as a balance element in the axis of Qirā' āt approach of linguists.
\end{abstract}

Structured Abstract: It is important to determine the conceptual framework when dealing with reading and linguistics. Both the linguistic composition and the term reading may evoke different contents. It is possible to encounter manifestations of these different perceptions in academic studies and practical field.

There is no other area that gives importance to definitions as much as scientific disciplines that are systematized by the Qur'an. Religious sciences have acted from the definition while basing their principles and elements. The majority of conflicts arise from definitions. There was not much controversy in the definitions made in transplant science. Therefore, there is not much controversy in definitions in the science of reading; because reading science is a transplant dominant area in size. It is before the Quran as a dictionary. By

\footnotetext{
${ }^{*}$ Dr. Öğr. Üyesi, Ankara Yıldırım Beyazıt Üniversitesi, İslami İlimler Fak. Temel İslam Bilimleri Asst. Prof. Dr., Ankara Yıldirım Beyazıt University, Faculty of Islamic Education, Department of Basic Islamic Sciences ORCID 0000-0002-8153-8181

akudat@ybu.edu.tr

Cite as/ Atıf: Kudat, A. (2020). Kur'an kırâatı ile Arap dilbilimi münasebeti üzerine, Turkish Studies - Religion, 15(1), 63-75. https://dx.doi.org/10.29228/TurkishStudies.41596

Received/Geliş: 03 February/Şubat 2020

Checked by plagiarism software

Accepted/Kabul: 25 March/Mart 2020

Published/Yayın: 30 March/Mart 2020

Copyright $(C)$ INTAC LTD, Turkey

CC BY-NC 4.0
} 
definition, the Quran is the host of the reading. The word (قراءة) is infinitive from the verb as a dictionary and means "to read, to pronounce".

The most important factor that prepared the birth of Nahiv science in terms of grammar of Arabic language was "irab" errors (lahn) which started to spread in society. Irab means explanation in the dictionary, derived from the root of "A-ra-be".

Since the meeting of the Qur'an, which is the word of Allah, with human beings, it has been well received by the linguists of this language, since the linguists of this language have gained close attention, and this interest and relationship between the reading and Arab linguistics has continued in many areas.

Works such as Meâni'l-Qur'an and İ'râbu'l-Qur'an can be described as works written in this manner. As of the period of codification, narration interpreters used various materials such as history, hadith, reasonnuzul in their efforts to understand what the Qur'an means, and the tafsir commentators made similar arguments as material for interpretation. The first of these is the reading and grammar. Indeed, it is possible to see examples of this in the first tafsir studies. Reading and Arab linguists tried to use the various aspects of the Quran with linguistic cells to explain the Qur'an. Thus, Arabic linguistics started to take its place in the group called Ulumu'l-Qur'an.

Arabic linguistics followed the context of intensive contact with the science of reading, which is one of the leading subjects of Qur'an and developing as a scientific discipline within the historical course.

In the historical process, linguistics with its branches such as eda, sarf and nahiv, together with the science of reading, like a twin, it has played very important functions both in the conservation of the divine speech and in the understanding of the correct knowledge. Based on this tight and inseparable relationship, Arab linguistics has always been taken into consideration in terms of determination of the reading aspects and the folding and interpretation of these aspects. While İbnü'l-Cezerî lists important factors in the science of reading, he emphasizes the method in reading and the sub-sciences of Arabic linguistics. He says that, "In order to know the style in the science of reading, sarf and nahv have a very important place in Arabic linguistics,". Although its basic basis is sanad-i sahih, linguistics is one of the three basic criteria in the promotion and interpretation of different aspects of the verse in the form and pronunciation of the words of the Quran in the context of the science of reading. This is called the " müvafakatü'l-Arabiyyeti" condition. While Arabic linguists also base their language grammar, they have cited the Qur'anic verses and various reading aspects of Qur'anic reference in the first degree.

As a scientific discipline, one of the two main trivets on which the reading is built is the amplitude and facility operation. The other is to determine the limits of this amplitude and facility. Accordingly, to set arbitrariness in the pronunciation of his words. Consequently, it is included in all its dimensions to prevent lahn, alteration ve distortion. In other words, the purpose of the reading is to protect the word of Allah against distortion and alteration. The science of reading is a shield against arbitrary readings, tafsir and interpretations, and while determining the limits, Arabic linguistics is one of the leading sciences that accompany it in this regard. From the beginning, it is known that the grammatical principles of Arabic linguistics should be a reference in the interpretation of the verses of the Qur'an. Subjectivity comes into play as long as these principles are violated, and arbitrariness becomes clear.

It is an indication of its importance that we can learn how the holy Qur'an is read by Hz. Mohammed to the finest detail thanks to this knowledge. Arabic linguistics also took references from the words of the Prophet. Indeed, "My Lord has taught me and made my nurture beautiful and I was given cevâmiu'l-kelim. The differences between Arabic linguistics and the reading were very important in shaping the thought of Islam.

By knowing the knowledge of the reading, it protects from making mistakes in the chant of the Quran. "Arabiyyetu'l-Fushâ" comes first among the sciences accompanying this science in the context of protection from error in the chant. As a matter of fact, "muvafakatu'l-Arabiyyeti" is one of the acceptance criteria of each Quran vech. Thus, by learning the science of reading, one also has the opportunity to learn Arabic linguistic rules; because the Islamic language was created in the first century, where nothing was lost from the most fluent Arabic fluency. Consequently, the angles that correspond to fluent Arabic became one of the reference sources for Arabic linguistics during the coding period. Because, it did not lose anything from the most fluent Arabic generosity, the reading occurred in the first century, and the Arabic linguistic rules got their share. 
Beginning from the coding period, Arab linguists have had different approaches to differences in reading. There are similar dilemma approaches that can be called ifrat and tefrit today. Halil b. Ahmed, who is considered to be the father of language and phonology, Sïbawayh, who is considered to be the father of Arabic linguistics and the students of Sîbeveyhi, who have made great contributions in the systematization of Arabic grammar, their positions and perspectives between linguistics and differences in reading can in fact give a picture of the controversies and controversial approach in this area. It can be said that these three schools constitute the source of the approaches that emerged within the history of these three schools in subjects such as Tawkif, Ictihad, Istishhad, Huccad, and Preference. In this context, we believe that revealing the approaches at that time will shed light on the source of the discussions in this area.

Many linguists, whose main areas of specialization are the Arabic language, have written works in the field of justification of the reading, thus, they feel that they are involved in this field by feeling the responsibility to refer to each of some different reading aspects. The factor that prompted these linguists to such a study, two of them aimed at the Quran, one of them is for the language schools they belong to, three motives can be mentioned.

Sîbeveyhi says that the Qur'an is mutawatır and some of the differences in reading may be gayr-i mutawatır. In his book, El-Kitâb, he brings evidence from the Qur'an close to five hundred. Some of them are different readings. Sîbeveyhi is a linguist. Like Basra school, it takes the sema (sky) to the center and runs the comparison. But the difference from other linguists is: It has an extremely respected attitude towards Qurrā imams and rawis. If there is a mistake, it should be sought in lehecat and selikas, not in the Qur'an. The Qur'an has a style in all the lehecats. Different forms of reading are Sunnah muttabaa, it is difficult to say that all language uses are detected. However, he says, the verses of the Qur'an and its reading aspects have been preserved.

Keywords: Reading the Quran and Qirā'āt, Linguistics, Qurrā, Sībawayh, Preference, Istishhad

Öz: Arap dilbilimi ve kırâat bilimi hizmet ettikleri gayede ikiz gibidirler. Kaynak ve delil bağlamında aralarında sıkı bir ilişki vardır. Genel uygulama kaidelerini temellendirirken birbirini referans göstermektedirler. Süreç içerisinde bu iki disiplin, kendi aralarında tartışmışlar, bazen karşılıklı tenkitlere mahal olabilmiştir. Tartışmaların odaklandığı iki temel husus, meselenin kaynak boyutu ve pratikliğinin referansıdır. Bu minvalde nakil, semâ', kıyas, illet ve istişhad çok sıkı kullanılan metotlardır. Dilbilimcilerin kırâatın muhtelif bazı vecihlerini tenkit etmeleri ve Arap dil gramerlerini gerekçelendirmede daha fazla başka argümanlarla istişhad yönüne gitmelerinin sebebi ne olabilir? Sîbeveyhi’nin bu husustaki konumu ve bu iki disiplin arasındaki sergilediği tavır kendinden sonra gelen dilbilimciler için neyi ifade etmektedir? Gramer ve kıyası önceleyen yaklaşım hicrî üçüncü asırdan itibaren yaygınlık kazanmıştır. Kırâat vucûhatını başta dilbilim olmak üzere birden fazla argümanlarla gerekçelendirme faaliyetleri sonucu vecihler arasında tercih etme eğilimi ortaya çıkmış hatta bazı vecihler tenkid edilebilmiştir. Meselenin gramer ve resm-i mushaf boyutunu öncelikli görenler farklı vecihler arasında ihtiyar yaparken kıyası öne çıkarma eğiliminde olabilmişlerdir. Kırâatın sened, müşâfehe, telakki ve tahammül boyutunu öncelikli görenler ise; tercih hususunda daha ihtiyatlı bir tavır sergilemiş̧lerdir. Kırâatın naklî boyutu bağlamında Arap dilbilimcileri, dilciler kadar mutedil değiller. Bu makalede dilbilimcilerin kırâat yaklaşımı incelenecek, sonra bir denge unsuru olarak Sîbeveyhi'nin tavrı ele alınacaktır.

Anahtar Kelimeler: Kur’an-1 Kerim Okuma ve Kıraat, Dilbilim, Kurrâ, Sîbeveyhi, Tercih, İstişhat

\section{Giriş}

Allah'ın sözü olan Kur'an beşerle buluştuğu zamandan itibaren şifahî ve kitabî olarak, apaçık bir dil olan Arapça olması hasebiyle bu dilin dilbilimcileri tarafından yakın ilgiye mazhar olmuş, birçok alanda Kırâat ile Arap dilbilimi arasındaki bu ilgi ve münasebet günümüze kadar devam edegelmiştir.

Meâni'l-Kur'ân ve İ'râbu'l-Kur'ân gibi eserler, bu minval üzere kaleme alınan eserler olarak nitelenebilir. Tedvin döneminden itibaren rivayet tefsirlerinin, Kur'an'ın ne dediğini ne demek istediğini anlama çabasında tarih, hadis, sebeb-i nüzul gibi muhtelif malzemeleri kullandıkları gibi, 
dirayet tefsirleri de buna benzer muhtelif argümanları yorum malzemesi yapmışlardır. Bunların başında kırâat ve gramer gelmektedir. Nitekim ilk tefsir çalışmalarında bunun örnekleri görmek mümkündür. Kırâat ve Arap dilbilimcileri, kırâatın muhtelif vecihlerini dilbilimsel hüccetlerle Kur'ân'ın izahında kullanmaya gayret etmişlerdir. Böylece Arap dilbilimi Ulumü'l-Kur'an denilen grup içerisinde yerini almaya başlamıştır.

Kur'ân mihverli tedvin edilegelen ve tarihi seyir içerisinde birer ilmi disiplin olarak gelişen konuların başında gelen kırâat ilmine yoğun münasebet bağlamında en fazla Arap dilbilimi takip etmişsir.

Tarihi süreç içerisinde edâ, sarf ve nahiv gibi dallarıyla dilbilim ilmi, kırâat ilmiyle beraber, ikiz misali, gerek ilahi kelamın muhafazasında gerekse sahih bilgiye dayalı manalarının anlaşılmasında çok önemli fonksiyonlar üstlenmiştir.

$\mathrm{Bu}$ s1k1 ve kopmaz münasebetten hareketle hem kırâat vecihlerinin tespiti hem de bu vecihlerin ihtiyâr ve tevcihi noktasında Arap dilbilimi, sürekli nazar-1 dikkate alınmıştır. İbnü’lCezerî, kırâat ilminde önem arz eden faktörleri sıralarken kırâatta usule ve Arap dilbiliminin alt bilimlerine vurgu yapar. "Kırâat ilminde usûlü bilmek adına Arap dilbiliminin sarf ve nahvin çok önemli bir yeri vardır," der. (İbn Cezerî, 1419: 50-57) Temel dayanağı sened-i sahih olmakla beraber, kırâat ilmi bağlamında Kur'an kelimelerinin biçim ve telaffuzundaki farklı kırâat vecihlerinin tevsik ve tevcihinde dilbilim üç temel kriterden biridir. Buna "müvafakatü'l-Arabiyyeti” şartı denir. Arap dilbilimcileri de dil gramerini temellendirirken, birinci derecede Kur'an ayetlerini ve muhtelif kırâat vecihlerini referans göstermişlerdir.

Bir ilmi disiplin olarak kırâatın üzerinde bina edildiği iki temel saçayaktan biri vüsat ve suhulet ameliyesidir. (Çetin, 2013: 230) Diğeri ise bu suhulet ve vüsatın sınırlarını tahdid etmektir. (Suyutî, 2018: 77-78) Buna bağlı olarak lafizlarının telaffuzunda keyfiliğe set çekmektir. Dolayısıyla bütün boyutlarıyla lahn, tağyir ve tahrife engel olmak da buna dahildir. Diğer bir anlatımla kırâatın gayesi, Allah'ın kelamını tahrif ve tağyire karşı korumaktır. Kırâat ilmi keyfi okuyuşlara karşı buna mebni olarak keyfi tefsir ve yorumlara karşı bir kalkan olup sınırları tahdid ederken (İbn Cezerî, 1986: 79) ona bu konuda eşlik eden ilimlerin başında, Arap dilbilimi gelmektedir. Bidayetten itibaren Kur'an ayetlerinin yorumunda Arap dilbiliminin gramer kaidelerinin mihenk olması gerektiği malumdur. Bu ilkeler ihlal edildiği nisbette öznellik devreye girer, keyfiliğin önü açılmış olur.

Kur'ân-1 Kerîm'in Hz. Muhammed s.a.v tarafından nasıl kırâat edildiğini en ince detayına kadar bu ilim sayesinde öğrenebilmemiz, onun öneminin bir göstergesidir. Arap dilbilimi de Hz. Peygamberin sözlerinden referans almıştır. Nitekim "Beni Rabbim terbiye etti ve terbiyemi güzel

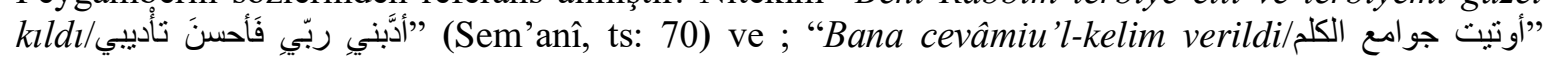
(Görmez v.d, 2013: 1/ 104) gibi nebevî anlatımlar buna işaret etmektedir. (el-Cahiz, 1995: 2/ 17) İslâm düşüncesinin şekillenmesinde, Arap dilbilimi ile kırâat farklılıklarının çok önemli katkıları olmuştur. (İbn Hazm, ts: 1/ 115)

Kırâat ilminin bilinmesiyle, Kur'ân-1 Kerîm tilâvetinde hatadan korur. Tilavette hatadan korunma bağlamında bu ilme eşlik eden ilimlerin başında "Arabiyyetü'l-Füshâ" gelmektedir. Nitekim "müvafakatü'l-Arabiyyeti" her bir kırâat vechinin kabul kriterlerinden biridir. (Kudat, 2015: 49) Böylece kırâat ilmini öğrenmekle kişi aynı zamanda Arap dilbilim kurallarını da öğrenme imkânı bulur; zira en fasîh Arapça fesahatinden hiçbir şey kaybetmediği hicrî ilk asırda kırâat ilmi teşekkül etmiştir. Dolayısıyla fasih Arapçaya uyan kırâat vecihleri, tedvin döneminde Arap dilbilimi temellendirilirken ona referans kaynaklarından biri olmuştur. Zira en fasîh Arapça sahavetinden hiçbir şey kaybetmediği, hicrî ilk asırda kırâat teşekkül etmiş Arap dilbilim kuralları da bundan nasibini almıştır. 


\section{Kavramsal Çerçeve}

Kırâat ile dilbilim münasebetini işlerken kavramsal çerçeveyi belirlemek önem arz etmektedir. Gerek dilbilim terkibi gerekse kırâat terimi farklı içerikleri çağrıştırabilir. Gerek akademyada gerekse pratik sahada bu farklı algıların tezahürlerine rastlamak mümkündür.

Dünyada en çok karmaşa dinî kavramlarda yaşanmaktadır. Kur'an mihverli sistematize edilen ilmi disiplinler kadar tanımlara önem veren başka bir alan yoktur. Dini ilimler prensip ve ilkelerini temellendirirken tanımdan hareket etmişlerdir. İhtilafların ekseriyeti tanımlardan kaynaklamaktadır. Nakli ilimlerde yapılan tanımlarda fazla ihtilaf olmamıştır. Dolayısıyla kırâat ilminde tanımlarda fazla ihtilaf yoktur; çünkü Kırâat ilmi nakli boyutu ağır basan bir alandır. Sözlük olarak Kırâat-Kur'ân'dan öncedir. Tanım olarak Kur'ân, kırâatın ev sahipliğini yapar. (قراء) kelimesi sözlük olarak (قرأ) filinden mastar olup "okumak, tilâvet etmek, telaffuz etmek" manasındadır. (İsfehânî, 1986: 606; el-Mes’ul, 2004: 269)

Kırâat ilminin bir terimi olarak en yaygın ve muteber kabul edilen tanımlarından birisini İbnü'l-Cezerî (ö. 833/1429) yapmıştır. Onun tanımı şöyledir; “Kur'ân kelimelerinin nasıl okunacağını râvîlerine nispet etmek suretiyle bu kelimeler üzerindeki farklı okuyuşları konu edinen bir ilimdir". (İbn Cezerî, 1931: 3) Kırâat, Kur'ân kelimelerinin edasıdır. Bu ifade, onun tümü için kullanılabildiği gibi cüz'ü için de kullanılmış ve ona da "kırâat" denmiştir.

Kırâat pratiğinde farklılıklar vardır, ama kırâat ilminde yoktur. Sabite ve şartları aynıdır. Kıraatın Kur'ân-1 Kerîm'in tarihinin karmaşık boyutu olarak görülmesi yanlıştır. Kırâat ilminin teorik ve pratik bağlamda girift ve karmaşık bir alan olmadığını Arap dilbilimi ile ortaya konulabilir.

İbn Kesir ve İbn Muhaysin Kur'an lafzının (قرأ) kökünden geldiğini ve camit olup özel isim olduğunu ve Kur'ân diye okunduğunu savunur. Bazıları da (قرن) kökünden geldiğini savunur. Bunlara göre en muteber tefsir Karain/قرائن'le yapılan tefsirdir, yani ayeti ayetle tefsir etmektir. Kur'ân'ın i'câz ve îcâzı burada gizlidir. (قرأ) kökünden geliyorsa kelimenin sonundaki "nun" harfi mastar eki olup kelimenin aslından değildir. Buna göre Kur'an, fu'lan vezninde mastarın mübalağas1 olarak ismi mefu'l olup çok okunan manasında olacaktır. Yeryüzünde en çok okunan kitap Kur'ân-1 Kerîm olduğundan bu yorum uygundur.

El-Ferrâ (ö. 207) ve Suyûtî (ö.911) Kur'ân kelimesinin müştak olduğunu savunurlar. Onlara göre Kur'an lafzı (قرن) kökünden gelir. Ayetlerin bunca farklı kırâatlere rağmen aralarında tezatlık yoktur aksine birbirine destekler bu da karine/قرينة'ye dayanır. Hülasa köken olarak ister müştak ister câmid olsun mana olarak hepsi birbirinden ayrılmaz. Câmid, Kırâat ilminin konusu Kur'ân kelimeleridir. Eda açısında ele alır. Bundaki ihtilafları ve ittifakları da ele alır.

Kiraatın konusu Kur'an'ın telaffuzdur. Kur'an'ın lafizlarını Hz. Muhammed (s.a.v.) telaffuz etti. Sahabe de bunu arz ve semâ metoduyla hıfz etti. Hz. Muhammed s.a.v. vefat edinceye kadar gerek namazda gerekse namaz dışında birçok defa hatmetti. Sahabe de sürekli birbirine öğretiyorlardı. Mükabele yapıyorlardı. Son Ramazan ayında da iki hatim yapıldı. Bütün bu süreç içerisinde farklı kırâat vecihlerinden bir külliyat oluştu, denilebilir. Bunları genel olarak ferş ve usul olmak üzere iki bölüme ayırmak mümkündür. Kırâat ilmi vucuhatı bu şekilde iki bölümde ele alır. Bu noktada iki önemli husus vardır. Birincisi "ma'zuvven li-nakilihi” ilkesidir, yani dayanaklardır. İkincisi ihtilaf ile ittifaklardır. Bu da ferş ve usuldür. İhtilaf ile ittifak hususları, kelimenin ya yapısında olur ya da bu kelime yapısının edasında olur. Kelimenin yapısı barındırdığı harfler ve biçimidir, eda ise onun nutku ve telaffuzudur. Özellikle kelimenin harf ve biçiminde olan kırâat farkl11ıkları için "ma'zuven li-nakilihi” ilkesi üzerinde hassasiyetle durulmuştur. Yani bu tür kırâat veçhinin kimden nakil edildiği hususu merkezi konumdadır. Arapça kaidelerine muvafik olmak burada tek başına yeterli görülmemektedir. Kırâatın geçerlilik şartları bağlamında zikredilen "senedi sahih" ilkesi bununla alakalıdır. Bu türden kıraat farklılıklarının dayanağı yedi harf yani seb'at-i 
ahruf/سبعة أحرف'tur. Kırâat-1 Aşere de Seb'at-i Ahruf'un içindedir. Zira bu terkipten maksat belli bir sayı değil, kesrettir.

“Kırâat ilmi, "ma’zuven li-nakilihi” mekanizmasıyla pratikteki keyfiliğin önüne set çeker.”

Kırâat ilminin eğitim ve taliminin dindeki hükmü, farz-1 kifayedir. Din alimleri lügat, tefsir ve kırâat ilmini bilmek farz-1 kifaye'dir. demişler. (İbn Cezerî, ts: 1/ 4) Kırâatın sünnet boyutu konusunda da fiili ve kavli sünnet olduğunu ayrıca takriri sünnet boyutunun da olduğunu söylemek mümkündür. القراءة سنة متبعة "Kı̂âat uyulması gereken bir sünnettir” kuralı bunun ifadesidir.

Dil bilimi olmayan diller kalıcı olamaz. Yok olmaya mahkumdur. Geleceğin dili olma iddiasında olan (evrensel) diller, doğru bir dil bilimine sahip olmak zorundadır. Arap dilbiliminin temeli irab (اعراب) tır. Nahiv (نحو) ilminin tedvinine saik unsur bu irap olgusudur.

Bir bilim dalının tutarlığı tanımlarıyla olur. Dolayısıyla tanımda yer alan sözlük anlam ile terim anlamın tutarlı oluşu o bilimin oturmuşluğunu gösterir. Dini ilimler geleneği en çok tanımlarının mükemmelliğiyle iftihar eder. Bu mükemmellik efradını cami ağyarını mâni olmasından gelir.

İrab, sözlükte izah anlamına gelmektedir, "A-ra-be” kökünden türetilmiştir.

Kişinin kendini ifade ettiğinde أعربَ فلانٌ عمَّا فِي نفِِ "Falancası içindekileri ortaya çıkard1Kendini ifade etti" demişlerdir. Istılahta ise, "Cümle içerisindeki kelimenin son harfinin amil nedeniyle almış olduğu değişken hareke veya harf yahut hazftır" şeklinde tanımlanabilir. İrab olgusunun üç boyutlu olduğunu söylemek mümkündür. (Nâsır, 1999: 21) Bunlar irabın ontolojik olgusu, irabın epistemolojik olgusu ve irabın aksiyolojik olgusu şeklindedir. İrabın ontolojik olgusu; irabın tarihin belli bir zaman diliminde ve belli muhitte var olduğunu ifade eder, yani Arap dilbiliminin temel dayanağ değildir, gerçekliği vardır. İrabın epistemolojik olgusu: irabın tarihi ve felsefi arka planını içerir. Dolayısıyla irab kaideleri, sahih bilginin ölçütü kabul edilmiştir. Asr-1 saadetten bize doğru tedvin edilen zengin mirasa ancak bu irap ile muttali olur istifade edilebilir. Fasih Arapçada irab, donuklaşmış, tarihe mal olmuş, nakli hüviyettedir. Buna semâ' (هكذا سمع) denir. Kiyas ve dayanaklar tali konumdadır. Kırâatta da nakil merkezi konumdadır. Buna sened-i sahih (هكذا أنزل، هكذا نقل) denir. $\mathrm{Bu}$ sabiteler sayesinde ilk asırda yaşayan biri ile günümüzde yaşayan birinin metinleri aynı şekilde anlamasını mümkün kılar.

İrabın aksiyolojik olgusu: İrabın interdisipliner boyutudur. Tüm bilim dalları metinleri anlaşılırken iraba bağl1 kalmaktadırlar. Diğer bir deyişle irab çerçevesinde mana üretmişlerdir. İrabın söz konusu olgusunu etkileyecek hem teorik hem de pratik bazı gelişmeler olmuştur. Sonradan üretilen telaüm, tealüf ve bağdaşım gibi nazariyeleri ile ıslâhü'l-luğat, teshîlu'l-luğat gibi girişimler, Kur'an'ın dolayısıyla kırâat vecihlerinin tevsikinde önemli, rol oynayan irab olgusunun ehemmiyetini zedeleyen girişimler olarak karşımıza çıkmaktadır. Zikredilen teori ve hareketler, Arapçanın en temel ilkesi olan nedensellik ilkesini reddetmeye dayanmaktadır. Bir dilin kaynağının belirlenmesi ve kullanımının gerekçelendirilebilmesi o dilin evrensel bir dil olabilme niteliği kazanmasını sağlar. İrab olgusu, Arapçaya her zaman ve mekânda geçerli olan ilkeler sunmaktadır. (Ferrûh, 1981: 1/35)

Kadim dillerden biri olan Arapça, i’rab hususiyeti sayesinde safavetini, aslî özelliklerini kaybetmeden günümüze kadar gelmiştir. Bu hususiyeti tam olmayan diller, tarihi süreç içerisini safvetini kaybetmiştir. Böylece sahih bilgiye ulaşmanın imkânı olan irab, dini menşeli İslam medeniyetinin geleceğe aktarılmasının önemli anahtarı olmuştur. Dolayısıyla irabın önemini kültürü geleceğe taşımak ve geçmiş/sahih bilgiye ulaşmak şeklinde özetlemek mümkündür. Bu nedenle irab, sahih anlamanın sigortası olarak başta Kırâat ilmi olmak üzere ve Kur'an etrafında şekillenen bütün ilimlerin ortak paydasıdır. 


\section{Tarihî Arka Plan}

Kırâat ilmi tarihi ve geleneği olan bir ilimdir. Kırâatın bir pratik bir de teorik boyutu vardır. Tanımlar teorik boyutuyla ilgilidir. Pratiğinin de bir tarihi ve geleneği vardır.

Bir bilim dalı olarak Kırâat ilminin tanımları, sabiteleri, ilkeleri tutarlıdır ve tarihe mal olmuştur. Dolayısıyla bu alan fazla müdahaleye açık değildir. Kırâat pratiğinde olsa bile Kırâat ilminde pek değişiklik olmaz. Tanımlar ve ilkeleri tarihe mal olmuş bir bilim dalıdır. Kırâat ilmi tarihi boyutu ağır olan bir bilim dalıdır. Kur'an kırâatı pratiktir ve Kırâat ilmine göre yapılır. Kırâat ilminin pratiğinde Hz. peygamberden bize kadar gelen süreçte değișiklik olmamıștır. Bunu Kırâat ilmine borçluyuz. O fasih, canlı, diri ve cevval olan Kırâat henüz bozulmadan ama bozulma tehlikesinin baş gösterdiği bir zamanda Kırâat ilmi temellendirildi ve sistematize edildi.

Arap dilinin tarihi serüvenine gelince, Ya'rub'un soyundan gelenlerin konuştuğu dile günümüzde Arap dili denmektedir. Ancak günümüze kadar Arap dili bazı merhalelerden geçmiştir. El-Arabiyetu'l-Baide veya Arabiyetu'l-Aribe, Ya'rub öncesi dönemde konuşulan dildir. Arkeolojik kalıntılar bu dilin varlığını gösterse de günümüze ulaştığına dair herhangi bir veri bulunmamaktadır. (el-Uceylî, 1427: 18-27) Sebeilerin bu dili konuştuğu düşünülmektedir. El-Arabiyetu'l-Müstarebe, Hz. İbrahim öncesi dönemde konuşulan dildir. Diğer bir deyişle Ya'rub'un konuştuğu dildir. ElArabiyetu'l-Müstarebe, Hz. İsmail'in Cürhüm kabilesinden biri ile evlenmesinin ardından gelişen dildir. El-Arabiyetu'l-Baide, cahiliye döneminde konuşulan Arap dilidir. Bu dönem Arap dilinin altın çağ1 olarak nitelendirilebilir. El-Arabiyetu'l-Füshâ, Hz. İsmail döneminden itibaren gelişen ve yerleşen dildir. Kur'an, fasih Arapçayı temele almıştır. Diğer bir deyişle sadece konuşulan mevcut lehçeyi değil bir bütün olarak Arap dilini esas almıştır. Bu nedenle mevcut lehçeleri aşmış ve ötesine geçmiştir. Arap dili sadece belli bir lehçe ile sınırlandırılamaz. Nitekim muallakat-1 seb'a Kureyş lehçesiyle yazılmamıştır. Ayrıca Ömer, İbn Mes'ud ve Abbas gibi önemli isimler Kureyşli olmalarına rağmen Kur'an'da nazil olan bazı kelimeleri anlayamamışlardır. (el-Uceylî, 1427: 20-22)

Nahiv ilminin doğuşunu hazırlayan en önemli etken toplumda yaygınlaşmaya başlayan irap hataları (lahn) olmuştur. Nahvi doğuran i'râb olgusudur.

Nahiv i'râb ile başladığına ve amacının ise dili koruyarak Kur'ân-1 Kerîm'in yanlış
okunmasının önüne geçmek olduğuna dair birçok rivâyetler vardır. Bütün bu rivâyetlerin ortak yönü ise, irâbın/nahvîn ortaya çıkışının Kur'ân-1 Kerîm kıraatında görülen lahn olgusuyla irtibatlı oluşudur. (el-Hâmis, 2012: 34-41)

I'râbda meydana gelen bozulmalar, nahvin temellendirilmesini zorunlu hale getirmiştir. Lahnin, Peygamberimiz devrinden beri, toplumda yaygınlaşmaya başladığına dair pek çok rivayet mevcuttur. Bu rivayetlerden bazıları şöyledir: Ebu Tayyip, "Biliniz ki Arapçada ilk bozulan ve öğrenilmesine en çok ihtiyaç duyulan şey i'râbtır, çünkü mevâlî ve müteârife arasında lahn ortaya çıktı." demiştir. Peygamberin yanında bir adam lahn yaptı, Peygamberimiz; "Kardeşinize doğruyu gösterin zira o, doğru yoldan saptı (yani konuşurken lahne düştü)," buyurmuştur. (Tantavi, 2012: 1617-18) Burada sapma ve sapıtma lehçe, şive veya başka bir seciyeden değil, i'râbda olmuştur. Asr-1 saadette, lehçe ve şiveler garipsenmezdi, ancak i'râbda yapılan hatalar garipsenirdi.

Fasih Arapçanın medar-1 iftiharı, sühulet ve vüs'attır. (Sîbeveyhi, ts: 1/ 6) Ancak başıboşluk yoktur. Gramatikal sisteme bağlı kalmak gerekir. Yukarıda zikredildiği gibi söz konusu kırâat ve dilbilim kuralların ihmale ve ihlale sebebiyet verecek teshil hareketleri uzun vadede zararı faydasından daha büyük olur. Nakli ilimlerin sabitelerini yerinden oynatmamak gerekir. İstikbalin lisanı ve cihanşümul olma iddiasını bu sabitelerle refere eder. Dilbilim bu meziyyeti, iştikak ve türetim mükemmelliği ile edat zenginliğine borçludur. Arap dilbilimi de temel gayesi itibariyle lahn, tağyir ve tahrife engel olmak için vardır, ancak her iki disiplinin birinci derecede teşekkülünde saik olan unsur, Kur'an'ın lahne karşı muhafazasıdır. 


\section{3. İki Disiplin Arasındaki Münasebet}

Nakli olmakla beraber her iki disiplinin teknik boyutu vardır. Kıyas ve sebep-sonuç münasebeti her ikisinde de yoğun yaşanmaktadır. Bu ortak özellikle her iki alana da ilel ve hüccet çalışmaları alt yapıyı oluşturmaktadır. Bu noktada yekdiğerini refere ettiği ve desteklediği görülmektedir. Bununla beraber, kırâat pratiğinde nakli hüviyetli olması ve telakkîye dayalı olması yönüyle farklılaşmaktadır. Diğer bir ifadeyle kırâatta semâ merkezi konumdadır. Senet olduğu yerde vecihler kıyasa vurulmaz. Ancak bu ilkeyi her vecih için söylemek zordur. Zira her bir vecih için ayrı bir senedi tespit imkanından mahrumuz. $\mathrm{Bu}$ eksende iki disiplin âlimleri arasında bazen tartışmalar olabilmiştir. (el-Ferrâ, 1955: 2/75) Bu tartışma ve münazaralar, zengin bir ilmi külliyatın oluşmasina vesile olmuştur.

Kırâatta herhangi bir veçhin geçerliliği için senet yanında resm-i mushafa -ihtimalen de olsauymak ve Arap diline -bir vecihle bile olsa- muvafakat etmektir. Ancak bunun kriterleri özellikle kıyası merkeze alan nahiv âlimleri tarafından tartışma konusu edilmiştir.

Sîbeveyhi (ö. 181) gibi bazı âlimler, sıklet (ağılık) ve hıffet (hafiflik) açısından harfleri sıralamakta ve kelimeleri derecelendirmektedir. O harflerden müteşekkil olan kelimeleri de temekkün (cümle içinde her yerde bulunabilme yeteneği) açısından sınıflandırma yoluna gitmektedir. Kırâat âlimleri de muhtelif kırâat vecihlerini senet, resm-i hat ve Arabiyyeye müvafakat bağlamında mütevatir, meşhur, âhâd, şaz, mevzu ve müdrec gibi isimlerle nitelemektedirler. Arap dilbilimcileri de bazı kırâatları ceyyid /ecved, bazılarını da redi’ olarak nitelemektedir. Suyûtî de, elİşârât fì Şevâzzi'l Kırâat (Suyûtî, 2004: 40-45) adlı eserinde, kırâatları üçlü tasnife tabi tutarak şu şekilde tanımlar; Kavî (kuvvetli), Mütevessıt (Orta) yani kuvvet ve zayıflıkta orta durumda olanlar, (ed-Dimyatî, 1285: 6) ez'af (Mutevessıt'dan daha zayıf olan) ve sonuncusu şaz olan kırâatlerdir.

Sîbeveyhi'nin yaşadığı dönemde Arapçada seciye ve selika'nın var olduğuna işaret ettiği irab olgusuna artık isim verilmiş ve irab, bir terim olarak 1stılah olunmuştur. Sîbeveyhi hem çok iyi bir gözlemcidir (semâ) hem de kıyası çok iyi bir şekilde kullanabilmektedir. Bu yönüyle yarı Basralı yarı Kufeli bir yaklaşım sergilemektedir. Hatırlanacak olursa Basra ekolü, korunmuş bir ortamda olduğu için dilde sadece yaygın kullanımı esas almıştır. Diğer bir deyişle yöntem olarak semayı öncelemiştir. Kufe ekolü ise merkezde, kozmopolit bir yapının içinde teşekkül etmiştir. Bu nedenle nadir kullanımları da dikkate almıştır. Yöntem olarak da kıyası benimsemiştir. Sîbeveyhi söz konusu iki ekol arasında denge kurmayı başarmıştır. Bu dengeli yaklaşım Kırâat için de söz konusudur, ancak Sîbeveyhi sonrası süreçte bu denge korunamamıştır. Zira Sîbeveyhi ve ondan önce yaşamış olan Kisâî (ö. 189) ve Halil b. Ahmed (ö. 174) gibi dilcilerin sema noktasında gerekli tüm çabay1 sergilediği dolayısıyla dilde mevcut olan bir kullanım var idiyse tespit edilmiş olma düşüncesi hâkim olmuştur; ancak nadir bazı kullanımlar var olduğu halde tespit edilmemiş olma ihtimali de vardır. Sîbeveyhi'den sonraki dilbilimciler, bu ihtimali göz ardı ettiklerinden kırâatın bazı vecihlerini tenkid edebilmişlerdir. Diğer anlatımla süreç içerisinde semâ ve kıyas açısından ilmi olarak yeterli doygunluğa ulaşıldığı inancı, söz konusu dengenin bozulmasındaki en önemli faktörlerden biri olmuştur. Söz gelimi Ebu Esved ed-Düeli otuz kişilik bir araştırma ekibi kurup dildeki kullanımları tespit etmeye çalışmıştı. Ne var ki buna rağmen Sîbeveyhi, Arapçada henüz rastlanmayan yaygın kullanımların olabileceği kanaatindedir. (el-Uceylî, 1427: 20-22)

\subsection{Dilbilim Alanında Eser Kaleme Alan Kurrâ}

Kırâat ilmi, Arp dilbilim ile beraber hem kitabet açısından hem de tilâvet açısından Kur'ân1 Kerîm'in 'nass'ına eşlik etmiş iki önemli disiplindir. Bidayetten itibaren Kur'an'ın daha iyi anlaşılabilmesi için bu iki ilmî disiplin, hâdim kılınmıştır. Kırâat âlimlerinden her biri, Arab dilbilimi konusunda donanımlı şahsiyetler oldukları için, genel olarak kurrâ, aynı zamanda, Arap dilbiliminde söz sahibidirler. Dilbilimciler de bir şekilde kırâat ilmiyle uğraşmışlardır. 
Kırâatları hüccetlendirme mevzuunda önde gelen âlimlerden biri, haklı bir şöhreti kazanan, Ebû Abdillâh b. Hâleveyh (370/980)'dir. İbn Hâleveyh hem kırâat hem de bir dilbilim âlimidir. İbn Hâleveyh'in "el-Hücce fi'l-Kırââti's-Seb" ve "Irâbu Selâsîne Sûra mine'l-Kur'âni'l-Kerîm eserleri Kırâat ve nahiv ilminde meşhurdur. (Güler, 2000: 402-407) Aynı zamanda meşhur bir dilbilimci olan bu zatın birçok eseri bulunmaktadır. Bunlar içinde (ليس في كلام العرب) adlı eseri en meşhurudur. Arap dilbilimi alanında meşhur olan âlimler içinde kırâat vucûhatına dolayısıyla bu ilme insaflı bir bakış açısıyla yaklaşan İbn Hâleveyh, kırâat vucuhatında dilcilerin hatalı addettikleri birçok hususun hakikatte Arap dilinin kendisinde -nadirattan olsa bile- var olduğunu ortaya koymaktadır. Ona göre Kur'ân'ın kendisine özgü bir dili ve üslûbu vardır. Dolayısıyla Lehecat ve gramer üstü olan bu üslubu belli bir gramer çerçevesine sığdırmak isabetli değildir. (Güler, 2000: 407) İbn Mucâhid (ö. 324/936) gibi kurrâ'dan bu alanda dersler alması onun bu isabetli duruşunda önemli etkisi olmuştur. (elHemedânî, 2010)

Kırâatların tahdidi safhasında bir kırılma hattı sayılan İbn Mücahidin "Kitabü's-Seb'a" adlı eserinde, kırâatın tahammül ve ahzi noktasında kaynak alınabilecek şahsiyetleri şu dört kısma ayırmaktadır. Bunlardan üçünün aktardığı kırâat vecihlerinin makbul, birinin ise merdud olarak tanımlar.

Birincisi, Arap dilbilimi konusunda mahir ve derinlik sahibidir. Aynı zamanda kurrâ'dan almış olduğu kırâatın senedi, hıfz ve zabtı hususunda da sağlam olanlardır.

İkincisi, Arap dilbilimi konusunda mahir ve derinlik sahibidir, ancak kırâat ve tilavet konusunda hıfz ve zabtı bulunmakla beraber lehçe veya şive farklılığı olabilenlerdir.

Üçüncüsü, Arap dilbilimi konusunda mahir ve derinlik sahibi olmamakla beraber, kurrâ'dan almış olduğu kırâatın senedi, hıfz ve zabtı hususunda sağlam olanlardır.

Dördüncüsü, Arap dilbilimi konusunda mahir ve derinlik sahibi olmakla beraber, kurrâ'dan ahz etmemiş kırâatın tahammülünde (yüz yüze müşafehe ile kırâat aktarımında) tahsil görmemiş olanlardır. (İbn Mücahid, ts.)

Basra mektebine mensub Arap dilbilim âlimi Ebû Alî Hasen b. Ahmed b. Abdilğaffâr elFarisî, (ö. 377/987) meşhur bir dil ve kırâat âlimidir. Dil filozofu olarak tanınan Kırâatların gerekçeleri mevzuunda ciddi bir eseri bulunan İbn Cinnî (ö. 392/1001) gibi birçok âlime ders vermiştir. Birçok meşhur dil âlimi ondan ders almakla beraber onun kıraat için hüccet getirme geleneğini kemale erdiren İbn Cinnî olmuştur. "el-Muhteseb" isimli kitapta şöyle der: Hz. Muhammed s.a.v.'e isnat edilen kırâat birikiminin hepsine sahip çıkmak gerekir. Başta Arap dilbilimi olmak üzere hüccet malzemeleriyle bu miras zabt u rabt altına alınmalıdır. İnterdisipliner bir konumda olan Kırâat ilmi sadece savtiyattan ibaret değildir. Bidayetten bize doğru intikali ile beraber birçok ilmi birikim ve edebiyat, belâğat ve i'caz gibi tarihi zenginlikleri de getirmiştir. Bilindiği gibi İbn Cinnî şaz Kırâatleri Arap dilbilimi ile hüccetlendirirken aslında hocası gibi bu zenginliği zabt altına almak istemiş olsa gerekir. (İbn Cinnî, 1994: 1/ 4-5) Gramer konusundaki gelişmelerin onunla kemale erdiği sayılan İbn Cinnî çalışmalarıyla aynı zamanda şazz Kırâatlerin de Arap dilbilimi ile hüccetlendirilebileceğini ortaya koymuştur. Kırâat varyantlarının dayanağı noktasında senet ve müşafehenin esas olduğunu vurgulamakla beraber, tevsik ve tercih safhasında destekleyici bir faktör olarak Arap dilbilimi ile hüccetin de ne kadar önemli olduğunu el-Mutasab" adlı eserini kaleme almasıyla ortaya koymuştur. (İbn Cinnî, 1994: 1/ 11) Arap dilbilimindeki eserleri içinde nahiv konusunda kaleme aldığı "el-ídâh" adlı eseri ve sarf konusunda ele aldığu "et-Tekmile" adlı eseri meşhurdur. el-Hücce li'l-Kırââti 's-Seb'a adlı eseri, kırâatları hüccetlendirme alanında yazılan ciddi eserlerden biridir. (el-Farisî, 1991) Doğuda Kırâat havzasında zikri geçen el-Farisî gibi Batı havzasından Mekkî b. Ebî Tâlib el-Kaysî, (ö. 437/1045) burada zikredilmesi gereken zatlardandır. O da kırâatta senet ve müşafeheyi merkeze almaktadır. El-Keşf adlı eseriyle Irak havzasının yaklaşımını benimsemiş ve Kırâat vecihlerini özellikle Arap dilbilim malzemesiyle gerekçelendirmiştir. Böylece bu iki disiplin arasındaki kopmaz münasebeti ortaya koymuştur. Onun 
izinden giden meşhur Kırâat âlimlerinden biri de ed-Dânî'dir (ö. 444/1053). El-Mudah adlı eserinde hem senedi hem de diğer iki temel kabul kriterini itibara almıştır. Hocası gibi hüccet bağlamında dilbilim ve resm-i mushaf' 1 merkeze almakla bu mevzuda nakil ile kıyas arasında dengeli bir yaklaşım ortaya koymuşlardır. Mağrib havzasından Mekkî'nin, gerek "et-Tebsîre " ve el -Keşf " adlı eserlerine (Mekkî, 1997) gerek ise de ed-Dânî'nin zikri geçen eserlerine bakıldığında hüccet ve tevcih ekseninde konuları daha sistemli ve metodik ele almaktadır. (Nirbânî, 2005: 317)

\subsection{Kırâatla İlgilenen Dilbilimciler}

Değişik sebeplerden dolayı fasih Arapçada baş gösteren hata ve bozulma, Kur'ân kırâatında lahn denilen yanlış okuyuşlara yol açtı. Kur'ân'ın nazil olduğu dilde meydana gelen bu arızanın farkına varan dil bilginleri, Arap diliyle ilgili grameri temellendirdiler. Sarf, nahiv ve sözlük alanlarında gerçekleştirilen bu dilsel çalışmalarda Kur'ân, temel dayanak olarak kabul edildi. Bir yandan, dilsel alandaki görüş ve düşüncelerini, Arap dilbiliminin temel kaynaklarından olan Kur'ân'a dayandırma ihtiyacını hissetmişlerdir. (Cerrahoğlu, 1988: 277) Diğer yandan lahnin Kur'ân'ın kırâatına da bulaşma tehlikesine karşı Kur'ân'ı lahn ve tahriften korumak için kırâat ilmiyle de yoğun alaka içinde olmuşlardır. Kırâat alanında meşhur olan kurrânın çoğu aynı zamanda dil bilimcidirler.

Arap dil bilimi alanında eserler kaleme alarak öne çıkan mütekaddimin âlimlerin ekseriyeti; birincisi gramer alanında İ'râbu'l-Kur'an, ikincisi sözlük alanında (Mekkî, 1997; Henâdî, 1408) Maani'l-Kur'an (el-Ferahidî, 2003) üçüncüsü ise nahiv veya kırâat gerekçeleri alanında ilel türü olmak üzere üç alanda en az birer eser kaleme almaya gayret etmişlerdir. (el-Ferrâ, 2005; Zerkeşî, 1415) Nitekim önde gelen kurrâ âlimlerin hemen hepsi, aynı zamanda çok iyi bir dil âlimi oldukları gibi meşhur dil âlimlerinin hemen hepsinin, Kur'an ve Kur'an kırâatı ile alakalı birer çalışmaları da vardır.

Basra mektebinin önde gelen dil bilimcilerinden ve kırâat ilminde de derinlik sahibi bir âlim olan Sîbeveyhi (ö. 180/796), "el-Hüccetu bi'l-kırââti ve el-Hüccetu li'l-kırââti” noktasında yani hem kırâat vucûhatında dil bilimsel hüccet noktasında hem de kırâat vücûhatıyla dilbilimsel kaidelerini refere etme noktasında müspet yaklaşımıyla bilinir. "el-Kitâb" adlı eseri bu konuda örnek alınması gereken bir kaynaktır. "el-Kitâb" adlı eseri sonraki nesillere aktarımı öğrencisi el-Ahfeş el-Evsat vasıtasıyla olmuştur. (es-Sirâfî, ts: ${ }^{51}$ ) Ondan sonra gelen dilbilimcilerin eserlerinde bu dengeli yaklaşımın muhafaza edildiğini söylemek zordur.

Sîbeveyhi'nin kırâata yaklaşımı kıyas değil semâ merkezlidir. Basra mektebine müntesib bir dilbilimci olarak belli kriterleri taşımayan vecihleri zayıf ve şazz olarak nitelediği olmuş, ancak kârîleri cehaletle veya i'râbda lahn yapmakla itham etmemiştir. Senet ve nakle gereken değeri veren Sîbeveyh'e göre naklî dayanağı olmayan kırâat vechi şazdır. Kırâatta şazz tanımı Sîbeveyh ve hocas1 Halil b. Ahmed ile girmiştir. (Dağ, 2000: 279) Kırâata uyulan sünnet/es-sünnetu'l-mutteba' gözüyle bakar. (Sîbeveyh, ts: 1/148) Sahih kıraatın Arapça'ya -bir vecih ile bile olsa- muvafakat etme," kriterine uymayan kırâat vecihlerini sadece bu sebepten dolayı tenkit etmeyi uygun görmez. (eşŞâtıbî, 1991: 5/54) Zira yukarıda değinildiği üzere ona göre tespit edilememiş nadir dil kullanımları olabilir. Arap dilbilim sahasında şaheser sayılan el-Kitab'da, (القرائة لا تخالف لانها سنة) "Kırâata muhalefet edilmez; çünkü kırâat uyulan sünnettir," demiştir. Nitekim eserinde dil kurallarına uymadığı için, bir kırâat vechini eleştirdiği vaki değildir. $\mathrm{O}$ bu yaklaşımıyla Kırâat ile dilbilim arasındaki uyum ve münasebeti bir şekilde ortaya koymaya çalışmıştır. (Sîbeveyh, ts: 2/154; Laşin, ts: 16-18) Kırâatların hüccetinden söz edildiğinde gerek el-hüccetu bi'l-kırâat (kırâatla hüccetlendirme) gerekse el-hüccetu li'l-kırâat (kırâatları hüccetlendirme) zaviyesinden olsun Sîbeveyh'in konumunu bir denge unsuru olarak vurgulamak gerekir.

Sîbeveyhi'nin kaleme aldığı eserlerinde grameri temellendirmek için yaklaşı üç yüz ayet ile İstişhat ettiği nakledilmektedir. (Cerrahoğlu, 1988: 277) Sîbeveyh, kırâatları değerlendirmede diğer dilbilimcilerin aksine gramer ve kıyası daha fazla öncelememiş olmasının sebebi, onun luğavî 
olan hocası Halil b. Ahmed'in senet ve rivayet içerikli olan derleme işlemleriyle daha ziyade meşgul olmasındandır. Dolayısıyla meselenin naklî tarafını önemseyen yaklaşımından etkilenmiş görünmektedir.

Sîbeveyhi'nin talebeleri ise el-Kitab adlı eserini başucu kitabı yapacak kadar grameri önemsemiş ve bir nevi bu gramer manzumesinin olduğu yerde senede gerek olmadığını düşünmüşlerdir. Gramer ve kıyası önceleyen yaklaşım hicrî üçüncü asırdan itibaren yaygınlık kazanmış ve kırâat vucûhatını başta dilbilim olmak üzere birden fazla argümanlarla gerekçelendirme faaliyetleri sonucu vecihler arasında, tercih etme eğilimi ortaya çıkmış, hatta bazı vecihler tenkit edilebilmiștir. Meselenin senet ve resm-i Mushaf boyutunu mukaddem görenler farklı vecihler arasında ihtiyar yaparken kıyası, daha mukaddem görenler, tercih yapma eğiliminde olabilmișlerdir. Kısa bir anlatımla kırâatın naklî boyutu yaklaşımında Arap dilbilimcileri, dilciler kadar mutedil değiller. Mesela semai öncelemekle bilinen Basra mektebi, bazen kıyâsı merkeze aldığı için senet ağırlıklı olan kırâatın bazı vecihlerini -kıyaslarına uymadığı için- tenkit edebilmişlerdir. (Hamza'nın kırâatına göre Nisa sûresi, 1. Ayette yer alan (والارحام) kelimesinin mecrur olarak okunmasını tenkid etmişler.) Hâlbuki Kur'ân kırâatında yedi harf ruhsatı, farklı lehçelere sahip toplumlara kolaylık sağlama hikmetine binaen verilmiştir. Arapların kullanmadığını veya yaygın olmadığını, bu yüzden dilsel kaidelere uymadığını söyledikleri kelime okunuşları, istikrâ ve semâ ile sabit olabilmektedir. (İbn Fâris, 1910: 19)

\section{Sonuc}

Tedvin döneminden itibaren Arap dilbilimcilerinin, kırâat vucûhatına karşı farklı yaklaşımları olagelmiştir. İfrat ve tefrit denilebilecek ikilemci benzer yaklaşımlar günümüzde de vardır. Dil ve sesbilimin piri addedilen Halil b. Ahmed, Arap dilbilimin piri addedilen Sîbeveyhi ve Arap gramerinin sistematik hale gelmesinde büyük katkıları olan Sîbeveyhi talebelerinin, dilbilim ile kırâat vücûhatı arasındaki konumları ve bakış açıları hakikatte bu alandaki ihtilafların ve tartışmalı yaklaşımın resmini verebilmektedir. Tevkif, içtihad, İstişhat, hüccet ve tercih gibi konularda bu üç ekol tarihi süreç içerisinde ortaya çıkan yaklaşımların kaynağını teşkil etmektedir denilebilir. $\mathrm{Bu}$ bağlamda o dönemdeki yaklaşımların ortaya konması bu alandaki tartışmaların kaynağına 1şık tutacağı kanaatindeyiz.

Asıl ihtisas alanları Arap dili olan birçok dilbilimci, kırâatların gerekçelendirilmesi alanında eserler kaleme aldıklarını, böylece bir nevi farklı kırâat vecihlerinden her birini refere etme sorumluluğunu hissederek bu alana müdahil olduklarını görmekteyiz. Bu dilbilimcileri, böyle bir çalışmaya sevk eden etken, ikisi Kur'ân'a dönük, birisi de kendilerine ait oldukları dil mekteplerine dönük olmak üzere, üç saikten söz edilebilir.

Sîbeveyhi, Kur'an'ın mütevatir olduğu, kırâat vucûhatından bazıları gayri mütevatir olabileceğini söyler. El-Kitâb adlı eserinde beş yüze yakın yerde Kur'an'dan delil getirmektedir. Bunlardan bir kısmı farklı kırâat vecihleridir. Sîbeveyhi dilbilimcidir. Basra ekolü gibi semâ1 merkeze alır, kıyası da işletmektedir. Ancak diğer dilbilimcilerden farkı şudur: Kurrâ imamlar ve râvîlere karşı fevkalade saygın bir tavrı vardır. Eğer bir hata varsa Kur'an kırâatında değil lehecât ve selikalarda aranmalıdır. Kur'an'ın bütün lehecâtın fevkinde bir üslubu vardır. Kıraat vecihleri sünnet-i müttabaadır, bütün dil kullanımlarının tespit edildiğini söylemek ise zordur. Ancak Kur'an ayetleri ve onun kıraat vecihleri korunabilmiştir, der.

\section{Kaynakça}

Aclûnî, İ. (ts). Keşfü'l-Hafâ ve Müzilü'l-illbas, Beyrut, ts.

Cerrahoğlu, İ. (1988).Tefsir Tarihi, Ankara.

Çetin, A. (2013). Kur'ân-ı Kerîm 'in İndirildiği Yedi Harf ve Kırâatlar, İstanbul, Ensar Neşriyat. 
Ebû Abdullah Huseyin el-Hemedânî İbn Hâleveyh, (2010). el-Hücce fi'l-Kirââti's-Seb'a, thk. Cemaluddin, Muhammed Salih, Darü's-Sahabe li'n-Neşr, Tanta, Mısır.

ed-Dimyatî, A. (1285). İthaf'u Fudalâi'l-Beşer, İstanbul.

el-Cahiz, M. (1995). el-Beyan ve't Tibyan, Misır.

eş-Şâtıbî, İ. (1991). el-Muvâfakât fî-Usûli’ş-Şerîa, thk. A. Draz, Beyrut.

Farisî, H. (1991). el-Hücce li'l-Kırââti's-Seb'a, Beyrut.

Ferrâ, Yahyâ b. Ziyâd, Ebû Zekeriyyâ. (1955). Meâni'l-Kur'ân, thk. Ahmed Yusuf Necâtî ve Muhammed Ali en-Neccâr, Dârus's-Surûr, Kâhire.

Firuzabadî, M. (2011). el-Ķâmusu'l-muhît, Dâru'l-Fikr, Beyrut.

Görmez, M. v.d, (komisyon) (2013). DİB, Hadislerle İslam, Ankara.

Güler, İ. (2000). "İbn Hâleveyh'in Gramer Açısından Tartışmalı Kur'ân Kırâatlarına Yaklaşımı", Uludağ Üniv. İlahiyat Fak. Dersi, sy. 9 , s. 402-407.

Hâmis, M. (2012). Mevsuatu'l-Musţalahi'n-Nahviyyî mine'n-Neş'eti ile'l-İstiķrâr, Dâru'l-kutubi'lilmiyye, Beyrut.

Henâdî, M. (1408). Zâhiretü't-te 'vîl fí i 'râbi'l-Kur'âni'l-Kerîm, Suudi Arabistan, Mekke.

İbn Ahmed, el-Halil. (2003). Kitâbü'l-Ayn (nşr. Abdülhamîd Hindâvî), Beyrut.

İbn Cezerî, M. (1419). Müncidü'l-Mukrîn ve Mür'idü't-Tâlibîn, Nşr. Ali b. Muhammed el-Umrân, Beyrut.

İbn Cezerî, M. (1986). et-Temhîd fî-Illmi't-Tecvîd, Tah: Hanım Küdduri, Beyrut, çev. Aydın Kudat, A. (2013) Ankara.

İbn Ebî Tâlib, M. (1407). Müşkilü i 'râbi'l-Kur'ân (nşr. Hâtim Sâlih ed-Dâmin), Beyrut.

İbn Ebî Tâlib, M. (1997). el-Keşf an Vücûhi'l-Kırâât, (thk. Muhiddin Ramazan), Müessesetü’rRisâle, Beyrut.

İbn Fâris, M. (1910). es-Sâhibî fi Fıkhi'l-Luğati ve Süneni'l-'Arab fî Kelâmihâ, el-Mektebetü'sSelefiyye, Kahire.

İbn Hazm, A. (1975). hmed b. Said, el-İhkâm fiusûli'l-Ahkâm, Beyrut.

İbn Mücahid, E. (ts.). Kitabu's-Seb'ati fi'l-Kırâ̂t, Kahire.

Kudat, A. (2015). Medeniyetler Gözergahı İpekyolu (ed: Bulut M), “Íbn Cezerî’nin İpek Yolu Coğrafyasına Bıraktı̆̆ İlmî Mîras", İstanbul.

Nâsır Betül N. (1999). Delâletü 'l-İ'râb lede'n-Nuhâti'l-Kudemâ, Bağdat.

Nirbânî, A. (2005). bdulbedî, el-Cevânibu's-Savtiyye fì Kütübi'l-İhticâci li'l-Kırâat, Haleb, Suriye.

Ömer, F. (1981). errûh, Târîhu'l-Edebi'l-Arabî, Beyrut.

Sem'anî, Ebû Sâ'îd A. (ts.). Edebü'l-İmlâ ve'l-İstimlâ, Beyrut.

Sîbeveyhi, Ebu Osman. (1985). el-Kitab, Beyrut.

Suyûtî, C. (2004). elalüddin, el-İşârât fí-Şevâzzi'l Kıraât, Tah: Abdulkerim el-Enis, (Mecelletü'lAhmediyye, say1: 17, 2004), s. 40-45.

Suyutî, C. (2018). elalüddin, el-ìtkân fî-Ulûmi'l-Kur'ân, Dâru'l-Kitâbi'l-İlmiyye, (tek cilt) Tahk. Muhammed Salim Haşim, Beyrut. 
Tantavi, A. (2012). Neş'etü'n-Nahvi ve Tarihu Eşheri'n-Nuhati, Kahire.

Uceylî, Salun Taha S. (1427). erhan Zahiretü'l-İrâbi fi 'l-Luğati'l-Arabiyyeti, Bağdat.

Zeccâc, ebu İshak. (2005). Me'âni'l-Ḳur'ân ve I'râbühü (nşr. Abdülcelîl Abduh Şelebî), Kahire.

Zerkeşî, B. (1415). el-Burhân fí 'ulûmi'l-K়ur'ân (nşr. Yûsuf Abdurrahman el-Mar'aşlî v.d.), Beyrut. 